\title{
Kalyana Mitta as the fundamental potential for happiness and suffering in Buddhist mindfulness counseling
}

\author{
Venty Venty ${ }^{*}$ \\ Deparment Guidance and Counseling, Faculty of Education, Universitas PGRI Semarang, \\ J1. Sidodadi Timur No.24, Kota Semarang, West Java 50232, Indonesiaa
}

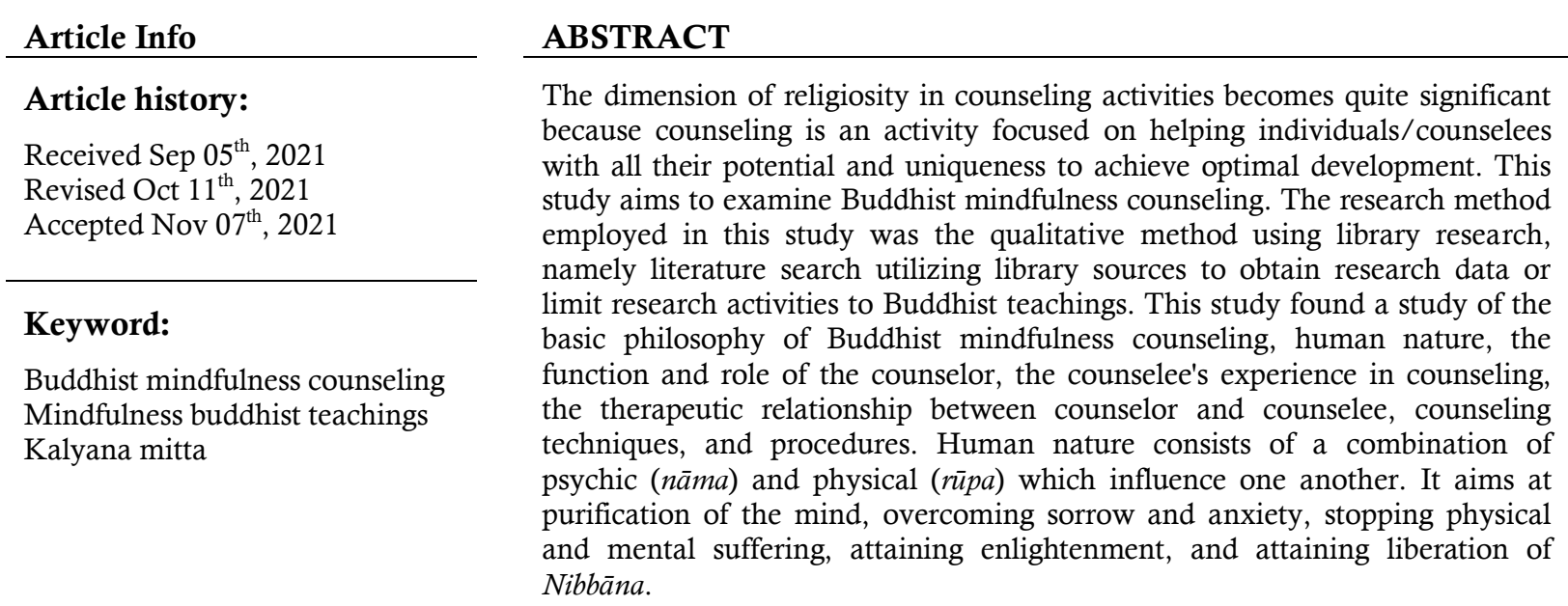

C 2021 The Authors. Published by IICET

This is an open access article under the CC BY-NC-SA license

(https://creativecommons.org/licenses/by-nc-sa/4.0

\section{Corresponding Author: \\ Venty Venty, \\ Universitas PGRI Semarang \\ Email: venty@upgris.ac.id}

\section{Introduction}

The 21st-century contact between the world of religion and counseling is often marked by antagonism and conflict. Conflict can arise in counseling when counselee and counselor differ quite sharply with respect to values and when counselee feels that values might be opposed or changed (Zinnbauer \& Pargament, 2000; Choudhuri \& Kraus, 2014). This condition is a problem that requires an understanding of the values and beliefs of the spirituality of the counselee (Watts, 2001; Adams, 2012). Having knowledge of religion or spirituality; acceptance of religious or spiritual expressions in communication; awareness of the limits of understanding and the ability to provide appropriate referral resources when needed (Shuler \& Durodoye, 2007; Stloukal \& Wickman, 2011; Cashwell Craig S \& Young, 2013).

The practice of counseling includes a strong moral, ethical, and religious or spiritual dimension, especially in Indonesia, upholding religion. The study and discussion of religious affairs or religious values are not intended to provide a parallel assessment between the culture created by humans and the religion produced by God. Rather, it considers religious values in relation to an empathic counseling process that takes into account historical, cultural, awareness of the client's beliefs, and experiences that affect the form of treatment (Ungsutharo,Siriwan,\&Ruangsanka, 2021). 
In Western countries, this has developed into what is called Pastoral Counseling (counseling based on the values of the Bible) among Catholics. Al-Qur'an verses that were developed for Qur'ani counseling as an individual effort to learn to develop fitrah and/or return to nature, by empowering faith, reason, and will (Sutoyo, 2009) is widely used and developed in Indonesia nowadays. Buddhist values contain a lot of counseling value but have not been presented conceptually and systematically like secular counseling. Buddhism can be considered a religion, philosophy, psychology, and morality because of its spiritual quest, comprehensive belief, in reality, a theory of human thought and behavior, solutions to alleviate suffering, and a recommended set of ethical behaviors (Zhou, Zheng, Zeng, Jiang, \& Oei, 2021). Buddhist counseling describes the process that Buddhist practitioners use by utilizing Buddhist teachings and interventions to help counselees reduce suffering (Rungreangkulkij \& Wongtakee, 2008). Studies related to Buddhist counseling that is currently popular are about Buddhist mindfulness counseling.

Buddhist mindfulness counseling is a comprehensive approach highlighting the importance of analysis and understanding of the counselee's condition. Mindfulness counseling is historically derived from the philosophy of Buddhist teachings(Susan M. Orsillo, 2005;Didonna, 2009; Hoyt, 2016) around 2500 years ago, adapted from meditation (Kabat-Zinn, 2011). This condition is in line with modern counseling approaches that have developed as conventional approaches. Examining Buddhist mindfulness counseling can parallel the secular counseling approach, applied to the implementation of Buddhist-based counseling. Mindfulness is naturally a systematic counseling approach. The service of Kabat-Zinn has introduced the core Buddhist teachings of the "Middle Way," to overcome the suffering that is closely related to the journey of life, and to turn meditation into mindfulness (Giraldi, 2019; Surmitis et al., 2018). The reflective meaning that is included in the counseling background is built from the sources of Buddhist teachings and has not been presented conceptually in systematic mindfulness counseling. This study aims to examine the mindfulness counseling of Buddhism in terms of Buddhist philosophy, human nature, the purpose of counseling, the function and role of the counselor, the counselee's experience in counseling, the relationship between counselor and counselee, and Buddhist mindfulness counseling techniques.

\section{Method}

This study was conducted using library research, to obtain research data or limiting research activities on Buddhist teachings from the Tipitaka scriptures (mainly sutta pitaka). There were several considerations for using library research: (1) It was used to answer research questions that are closely related to library research issues (in this case Tipiaka). (2) Literature study is needed as one of the separate stages, namely preliminary research to further understand the new symptoms faced by the counselee. (3) library data remains reliable for answering research problems by collecting library data, reading, and taking notes, and processing research materials (Zed, 2018). The sources of data for this study were the Buddha's teachings in the Tipi aka scriptures. Data sources consisted of primary sources. The primary source consisted of the sutta pitaka, supported by other commentaries (atthakata).

\section{Results and Discussions}

Buddhist mindfulness (satipatthāna) counseling analysis is parallel to the secular counseling approach that can be applied as an implementation of Buddhist counseling. Mindfulness counseling naturally is a systematic counseling approach in line with the development of counseling. Spiritual seekers have used mindfulness techniques to help train the mind to concentrate, stay focused in the moment and influence increased tolerance (that is, the ability to tolerate difficult feelings in oneself or others). This skill is important for the counselor. Several reviews of the mindfulness literature reveal that researchers and doctors are effective in curing a variety of physical health and mental problems with significant results. The Buddhist mindfulness counseling framework is an approach and technique used in counseling activities in accordance with the characteristics of the counselee and the potential of the counselor (Tuicomepee et al., 2012; Rungreangkulkij \& Wongtakee, 2008). Mindfulness is the main approach that can be used as an entire individual and group counseling program. This approach is used as primary (main) counseling or as secondary/additional counseling depending on the counselee concerned.

Mindfulness is a quality of self-awareness, which includes awareness and attention and must be distinguished from mental processes such as cognition (planning-supervision), motivation, and emotional states (K. W. Brown \& Ryan, 2003). Mindfulness involves how a person sees, feels, knows, and loves what is focused on at the moment and facilitates greater focus and awareness (Jon Kabat-Zinn, 2007). This approach involves focused attention in the here and now and with a nonjudgmental attitude using the basic units of intention, attention, and attitude. Mindfulness requires a person to open up and accept current experiences, 
develop tolerance, difficult feelings that are expressed in oneself and by others. The mindfulness approach allows collaboration and changes in the behavior or attitudes while still emphasizing the importance of therapeutic relationships and not questioning cultural values or practices. A straightforward mindfulness approach (easy, hones, straightforward), which is physiological and cognitive because it focuses on thoughts, events, and behaviors as well as attitudes of the current counselee instead of nature, socio-cultural background, or cultural beliefs (Erford, 2015). The things that are cultivated through mindfulness therapy are attention and awareness of thoughts, emotions, and bodily sensations.Kabat-Zinn (1992) explains that mindfulness is a process that delivers the quality of attention to here-now experience without the need to elaborate, without judgment; and acceptance of any thought, feeling, or sensation arising from the center of the present waking state of consciousness. It is as if the experience when walking on the beach, feeling the sensation when the feet step on the sand, and when seeing people wearing bikinis that are recognized as a visual process, namely the eyes-catching human objects wearing bikinis. Everything that is felt, seen, heard, emotional reactions, and thoughts that accompany is noticed as a mental event arising in the stream of consciousness. The state of mindfulness means that thoughts and feelings are mental events that arise in the mind without the need to over-identify and react automatically with behavioral habits that tend to be emotionally motivated. Mindfulness is a state of self-observation, giving the distance between perception and response. Thus, mindfulness allows the mind to respond to situations more effectively in real reality.

\section{Basic Philosophy of Buddhist Mindfulness Counseling}

Humans are seen to have the fundamental potential for happiness and suffering. The seeds of suffering and happiness basically arise in the life process. In essence, physical conditions, feelings, thoughts, and various phenomena are the basic potentials that can cause happiness or suffering. The main goal of humans is to get rid of the suffering they experience (Amaro, 2015). No human being has the basic motive of wanting to suffer physically or mentally. Activities carried out by humans are basically to get a sense of happiness from simple to complex actions.

The fundamental philosophy of Buddhist mindfulness counseling is a practical application as a counseling/therapeutic formula to discover the true nature of life. The philosophical basis of Buddhism is contained in four noble truths. The first noble truth states about suffering as natural truths such as birth, aging, sickness, death, association with what is displeasing; parting with what is fun, not getting what is wanted (Bodhi, 2003; Eells, 2012). The second noble truth is that suffering is caused by craving (tanha) (Walshe, 1995; Rungreangkulkij \& Wongtakee, 2008) accompanied by pleasure and lust, seeking pleasure i.e. craving for sensual pleasures, craving for becoming, craving for annihilation. The third noble truth is the cessation of suffering that is through the process of cessation of tanha. The fourth noble truth is the path to the cessation of suffering, namely the Noble Eightfold Path (Bodhi, 2003). The way out of suffering referred to is an eightfold path consisting of the wisdom aggregate of right understanding (samma ditthi) and right intention or aspiration (sammā sankappa). The aggregate of wisdom that flows into moral commitment includes right speech (sammā $v \bar{a} c c \bar{a})$, right action (sammā kammanta), and right livelihood (sammāājìva). Moral nature will naturally bring a commitment to right effort (sammā vāyāma), right mindfulness (sammā sati), and right concentration (sammā samādhi) (Karunamuni \& Weerasekera, 2019).

Buddhist values perpetuate a system of counseling for individuals throughout life towards the full reality of the nature of human consciousness (Safran, 2013). This is not just a passively heard spiritual sermon, not a theory for higher-level discission and logical analysis. The system of consciousness is experienced by each individual, by contemplating and reflecting on various objects and functions of the body and consciousness. Mindfulness practice in order to realize the totality of life that changes as a process that is empty of impermanent, full of suffering, and has no central personality core or self (Shen \& Midgley, 2007).

Suffering or problems come from wrong reactions to the phenomena of life ( Lutz et al., 2015). The pleasant sensations of the physical, feelings, thoughts, and phenomena which are overly responded to or their existence wants to be maintained gives rise to new suffering. As a simple illustration, you feel the comfortable air and want to feel it continuously without understanding that the comfort of the air is only a momentary phenomenon and changes with another atmosphere (Jeon, 2021). The unpleasant sensations of the body and the mind that are perceived as permanent and arising from excessive dislike are a form of potential suffering.

The understanding of this insight into the truth is completely instilled through understanding suffering completely, with a self-awareness that is the vision, knowledge, wisdom, understanding, and enlightenment that arise in oneself regarding things that have never been heard before (Bodhi, 2003). Enlightenment to suffering can be achieved through training in the creation of mindfulness (satipațthāna) on the body, emotions, minds, and various phenomena. A new perception or concept of physical and mental experience can only be obtained through direct observation or attention. Immediate attention is something that is genuine and focused on the main topic, resulting in a very valuable insight. Increased attention leads to thorough understanding 
and problem-solving. The process of insight into the natural truth about suffering is seen as a natural reality, must be understood, and finally has been understood.

\section{Human nature}

Humans consist of a combination of psychic (nāma) and physical (rüpa) which influence each other (Walshe, 1995). Physical and psychological in the form of material and mental which consists of a combination of elements that undergo changes continuously. Changes in the psychological and physical aspects are able to cause problems as well as be able to solve them. Problem-solving can be done by understanding the cause of the problem in the form of mental dullness to see reality clearly. The vision of reality is done through direct observation. Direct observation is not an attempt to attain, to create a certain calm, but rather looks at physical and mental reality "as it is" and simple perspective. Based on the literature, direct observation is a form of vision or clear vision without delusions (Bodhi, 2003) which focuses on the process, and nature of interdependence (Bhikkhu Bodhi, 2012; Bodhi, 2003). Thus, it will produce a tangible view of ever-changing, unsatisfactory, and insubstantial phenomena.

Buddhism views what humans call the five aggregates of life (pañca khandha) consisting of the elements of the body, feeling, perception, mental forms, and consciousness. The four aggregates other than the body are the mental element(näma). The body and mind exist in the form of material and mental units consisting of many elements, constantly moving, interdependent, and interacting with each other without an independent personal core substance (Hoang, 2019); The mind consists of feelings, perceptions, forms of thought, and consciousness while the physic consists of the element of liquid, solid, motion, and fire or heat. Through the six bases of the senses, namely the eyes, ears, nose, taste or tongue, body or tough give rise to bad and good deeds. Bad deeds stem from greed (lobha), hatred (dosa), and delusion (moha) which result in physical and mental suffering. Actions associated with non-greed (alobha), unrighteousness (adosa), and wisdom (pañña) bring progress and benefit to the individual.

Initially, human existence was ego-consciousness, ego-aware, or self-aware. Awareness of oneself is expressed as an affirmation of oneself (O'Hagan, 2021). Self-affirmation involves individualizing oneself, being differentiated and discriminated against from what is not self, not me, or non-ego. However, selfaffirmation brings solutions to oneself (Indunil Philip Shantha, 2019; Quek, 2007).

\section{Counseling purpose}

Nissanka (2009) explains that Buddhist counseling/therapy has the main objectives, namely: (1) reducing the mental pressure of the counselee, (2) doing catharsis or purifying the counselee's unconsciousness, (3) communicating well with the counselee, (4) exploring or investigating the mind subconscious and conscious mind of the counselee, (5) directing the counselee to be able to see various negative mental conditions that cause problems, (6) training counselee socialization with the general public, (7) gradually increase selfunderstanding, (8) carrying out counselee rehabilitation physically, psychologically, socially, and economically.

The purpose of counseling is to train the mind, calm the mind, focus on the present, overcome sadness, anxiety, stop physical and mental suffering, attain insight, and finally attain the liberation of Nibbāna (Walshe, 1995). Purification of the mind from greed, hatred, ill will or rejection, delusion, wrong views, pride, doubt, laziness, and aversion, restlessness and regret, shamelessness, and fearlessness of the consequences of verbal wrongdoing, actions, and thoughts (Gunaratana, 2011).

To achieve happiness is basically influenced by mental attitudes or mental reactions to the realities of life. Mental attainment of an understanding of reality or a bright view results from the development of mindfulness. Direct observation of objects, bodily processes, and mind as impermanent, suffering, and without essence (Mahasi, 2006). Increasing the ability to deal with various turmoil that arises from mind and body in a better way, eliminating negativity, having the self-control to increase the ability to socialize well.

\section{Functions and Roles of the Counselor}

The counselor in this case is a guide, in the sense of being a good friend (kalyana mitta). Mindfulness counseling focuses on the full awareness of the body, feelings, thoughts, and mind objects. The role of the counselor in mindfulness comes from the perspective or belief and the counselee's thinking in facing and seeing the realities of life as it is (Lee et al., 2017). In terms of the role of the counselor, it is not on the technique of changing the counselee, but on how to help the counselee's view change the wrong way of looking at the phenomenon of one's own life. The goal of counseling is an inner development process that requires direction from experienced parties or professional counselors. The counselor in the counseling process needs to understand the implementation mechanism, direction, progress, setbacks, and the various physical and psychological symptoms that arise. 
The counselor assists the counselee in the mindfulness counseling process so that the counselee does not experience obstacles in counseling. Internal and external barriers can cause laziness and various negative psychic phenomena which may be disturbing if not properly understood. The mindfulness counseling process requires counselors who are experienced in handling problems, so that the problems faced get enlightenment (O’Brien \& Likis-Werle, 2020).

During the counseling process through mindfulness, individual interviews are conducted intensively to help the counselee resolve problems more quickly. After the counselee describes his experience, the counselor will ask more detailed questions to the counselee before providing explanations and instructions. The counselee presents the results of his experience for approximately ten minutes. The delivery of experiences is short, precise and clear so as not to drift into useless conversations. The first to be reported in this case is about time efficiency or the percentage of time spent exercising mindfulness. Honesty is very helpful in the next process. After reporting the effective time, the next step is to report the conditions experienced while standing, walking, sitting or lying down.

The relationship between the counselor and the counselee is established through a process of interviewing and instructions that are humane and not rigid. A friendly and humane atmosphere becomes the basis that the counselor does not act as a guide (acariya) but rather in the context of a good friend (kalyana mitta). The counselor's patience, compassion, and concern are real works that can accelerate the counselee to be free from problems through mindfulness counseling.

\section{Counselee's Experience in Counseling}

Changes in the mindfulness counseling process depend on the counselee as an individual who has the potential to solve the problem or suffering he is facing. A painful experience for the counselee is not avoided, but needs to be paid attention to how the counselee can realize with mindfulness, dive into deep problems so that the counselee has direct experience(Marma, 2017) of the suffering or problem at hand and does not escape or distract from the problem at hand. The counselee will then learn from suffering, explore suffering or problems as problems that occur naturally (Lee et al., 2017).

How counselees practice to recognize suffering, knowing that suffering can teach wisdom will make counselees can learn a lot from suffering. If you look deeply at the nature of suffering, the counselee can gain insight into how he can get out of this situation. That is the reason suffering (dukkha) is called the noble truth in Buddhism. Suffering is noble, because contemplation of suffering can provide insight into how to get out of suffering and transform it.

To let the suffering go away, the counselee first needs to admit it in the space of consciousness. But recognition in contemplation does not start from "I am suffering" but from, "it exists because of the presence of suffering", because we no longer identify with the problem, but merely recognize its existence. The tendency of the counselee to view life from the point of view: "this is my problem", thus, the counselee is thought to have been honest and straightforward with himself. The counselee is then more likely to reinforce such an attitude of thinking because life continues to operate based on wrong views. However, a real view can emerge: impermanent, unsatisfactory and not self. 'There is suffering is a very clear and precise admission that at this moment, there is a sense of unhappiness. Through mindfulness, the counselee will be able to bear his whole life where the experience of the counselee in realizing and understanding the source of the suffering or problem is his own desire.

\section{Therapeutic Relationship between Counselor and Counselee}

The qualities of the therapeutic relationship between the counselee and the counselor include empathy, warmth, understanding, acceptance, and compassion. Research reviews show that empathy is more influential in counseling interventions (Luberto et al., 2018; Cheryl L. Fulton \& Cashwell, 2015). The relationship between counselor and counselee filled with empathy (Leppma \& Young, 2016) and compassion (Luberto et al., 2018) in Buddhist mindfulness practice is defined as an explicit intention to develop understanding as it is. Empathy for others is a natural extension of self-compassion developed in the practice of mindfulness (Ivers et al., 2016).

Developing compassion and empathy for the counselee and at the same time acknowledging that the counselee cannot make a big difference in the quality of life needs to be understood by the counselee first. The quality developed in mindfulness practice is development balanced with serenity. An attitude of indifference that describes an open acceptance that all the counselee's experiences also needs to be applied. There are three types of counselees based on the Buddhist parable. The first is that there are counselees who do not care whether they get proper nutrition, appropriate medicine, and adequate care or not so that they do not recover from their illness. The first type of counselee means getting the opportunity to listen to instructions or not, but not achieving perfection in a good state. The ability of the first counselee is to be able to understand the words 
of instructions given but cannot reach the stages of enlightenment. There are counselees who get nutrition, medicine, or appropriate treatment or not, but are still healed from their illness. The second counselee has the opportunity to listen to the training instructions or not, and still achieve perfection in a good condition and able to penetrate the realities of life. The third counselee can only recover with adequate nutrition, medicine, and care and can never recover without getting help. The third type will gain enlightenment or the breakthrough of natural law by receiving detailed and repeated instructions (Bodhi, 2012).

\section{Application: Mindfulness Counseling techniques and procedures}

Buddhism emphasizes the formation of consciousness or mindfulness as a strategy or a way to perfectly solve problems of physical and psychological pain and attain liberation from the underlying problems. The problems in question are in the form of sadness, various physical sufferings and mental suffering.

Relief of various sufferings or problems is carried out by increasing attention and reflection, so as to give rise to a penetration of the truth of the problem. The step taken is to observe the body or physical body in the body then contemplate on it, observe the feelings it has and reflect on it. Observing the mind is followed by contemplating and practicing observing and contemplating mind objects. Referring to the basic practice of mindfulness, it can be concluded that the foundation that is carried out to increase attention or awareness as a capital to understand reality is mindfulness in relation to the body, attention to feelings, attention with respect to thoughts, and mind objects.

The practice of mindfulness counseling includes two forms of approach meditation, namely onepointedness of mind and clear understanding. Oneness of the mind functions to suppress various mental hindrances, while clear understanding meditation serves to penetrate the reality of life perfectly. Chaotic thoughts are collected at the "present" moment continuously so that in the working process it will use the accumulation of thoughts and understanding. Mindfulness and contemplation of the body or body is basically the work of the one-pointedness of the mind. The other three forms include mindfulness and contemplation of feelings, mindfulness and contemplation of the mind and mindfulness and contemplation of mind objects which is basically clear understanding meditation.

The Buddha's systematic division deals with the foundations for increased mindfulness or awareness, which are intended in detail either to facilitate implementation in terms of practice or as a complete guide to practice. In the first stage regarding mindfulness of the body, the Buddha stated practical instructions in sentences full of practical values. Meanwhile, the practice of mindfulness and contemplation of the body is carried out by paying attention and reflecting on the body persistently, full of vigilance and with a mind that has a clear understanding so that it can overcome greed and sadness as a result of understanding the world (Nakayama, 2021). Statements of energy, full awareness, clear mind, and understanding of the world as it really is also applied to mindfulness and contemplation of feelings, thoughts and mind objects.Mindfulness techniques are applied to the mind and various phenomena. Thoughts and phenomena are not regarded as constant, so their arising does not cause any fundamental complexity. Problems arise because of a misunderstanding of reality related to physicality, feelings, thoughts and various phenomena. Therefore, the step of attention to understand the essence of the four is the main key to healing.The application of Buddhist mindfulness counseling can be applied to all walks of life, both individuals and groups, such as parent/child counseling, marriage and family counseling, individual counseling for children and adolescents, counseling that is corrective and rehabilitation, development, group counseling, drug abuse, and those related to the elderly where this is a development model. This approach is ideally suited for the prevention of mental health and eliminates a range of conditions that hinder mental development through mindfulness.

Table 1. Concept Map of Buddhist Mindfulness Counseling

\begin{tabular}{|c|c|c|}
\hline No & Aspect & Description \\
\hline 1 & Figure & Siddharta Gotama (born 623 BC) \\
\hline 2 & Concept & $\begin{array}{l}\text { - Humans are seen to have the fundamental potential for happiness and suffering. } \\
\text { - The seeds of suffering and happiness basically arise in the life process. } \\
\text { Physical conditions, feelings, thoughts, and various phenomena that are } \\
\text { continuously in process are essentially fundamental potentials that can cause } \\
\text { happiness or suffering. } \\
\text { - The main goal of humans is to get rid of the suffering that is experienced } \\
\text { (Nanamoli \& Bodhi, 1995). }\end{array}$ \\
\hline 3 & Essence & $\begin{array}{l}\text { - Humans consist of psychic and physical influences each other (Walshe, 1995). } \\
\text { - Physical and psychological in the form of material and mental which consists of } \\
\text { elements and elements undergo changes continuously. } \\
\text { - Changes in psychological and physical aspects can cause problems as well as }\end{array}$ \\
\hline
\end{tabular}




\begin{tabular}{|c|c|c|}
\hline No & Aspect & Description \\
\hline & & $\begin{array}{l}\text { Solutions. } \\
\text { Problem solving can be done by identifying the problem, the cause of the problem, } \\
\text { alleviating the problem so that the reality can be seen clearly. } \\
\text { Humans have the potential to realize the totality of life as an impermanent process, } \\
\text { full of suffering and without a central personality core or self. }\end{array}$ \\
\hline 4 & $\begin{array}{l}\text { Assumption } \\
\text { of } \\
\text { problematic } \\
\text { behavior }\end{array}$ & $\begin{array}{l}\text { - The individual has the capacity to understand problems, eliminate, attain insight } \\
\text { and develop the path to the cessation of suffering. } \\
\text { - All human problems range between mind and body where the effort to solve it is } \\
\text { by increasing understanding of mind and body. All psychological experiences such } \\
\text { as pain and pleasure, sadness and happiness, good and evil, life and death, are } \\
\text { independent of external factors. Everything is the result of one's own thoughts and } \\
\text { the result of activity. }\end{array}$ \\
\hline 5 & $\begin{array}{l}\text { Counseling } \\
\text { Purpose }\end{array}$ & 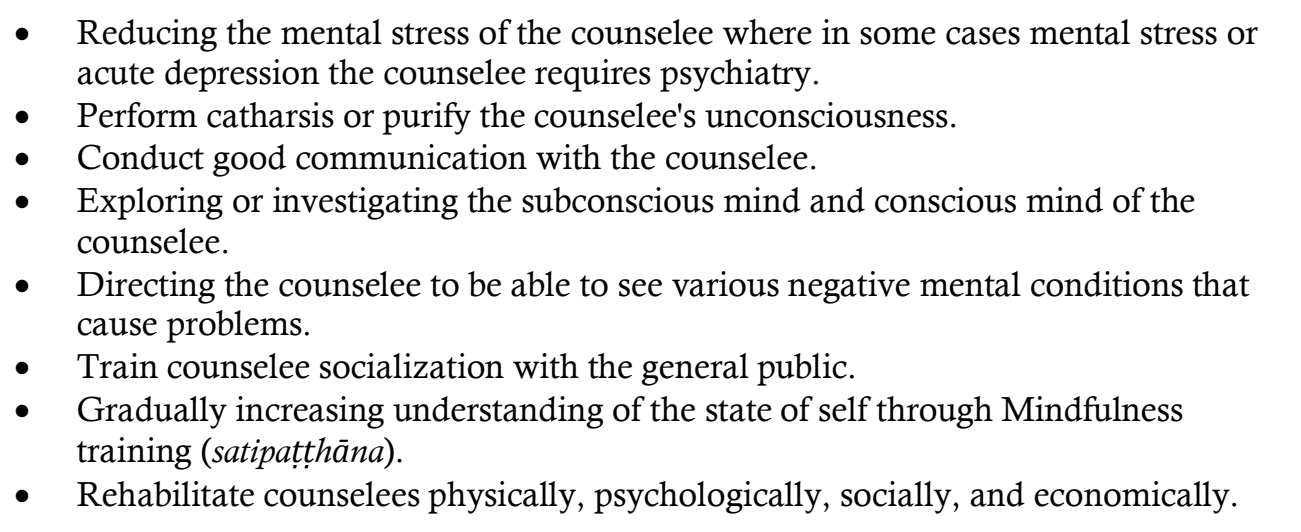 \\
\hline 6 & $\begin{array}{l}\text { The Role of } \\
\text { the } \\
\text { Counselor }\end{array}$ & $\begin{array}{l}\text { - A friendly and humane atmosphere forms the basis that the counselor does not act } \\
\text { as a guide (acariya), but a good friend (kalyana mitta). } \\
\text { - Helping the counselee to contemplate full awareness of the body, feelings, } \\
\text { thoughts, and mind objects. } \\
\text { - Assist the counselee in realizing the natural processes of his body or body: full } \\
\text { awareness of the breath, body posture (sitting, standing, walking and lying down), } \\
\text { awareness with a clear understanding of the body, contemplation of the detestable } \\
\text { qualities in the body, contemplation of the elements - the basic elements of the } \\
\text { body (solid, water, motion, heat), contemplation of buried corpses. } \\
\text { Accompanying the counselee to contemplate or realize pleasant, unpleasant, } \\
\text { neutral feelings, including physical happiness and physical pain. }\end{array}$ \\
\hline 7 & $\begin{array}{l}\text { Counseling } \\
\text { Techniques }\end{array}$ & $\begin{array}{l}\text { - The role of the counselor in mindfulness (satipatthāna) counseling is centered on } \\
\text { the counselee. The counselor as a guide in this sense also means a good friend } \\
\text { (kalyana mitta). } \\
\text { - The quality of the positive therapeutic relationship between the counselee and the } \\
\text { counselor must be filled with empathy, compassion, warmth, understanding and } \\
\text { acceptance and paying attention to blaming, ignoring or rejecting behavior. } \\
\text { The relationship between counselor and counselee should be accompanied by a } \\
\text { sense of tolerance. When practicing mindfulness, strong emotions can come on } \\
\text { their own, which needs to be recognized through the attitude and acceptance of } \\
\text { any other mental or physical sensation event. }\end{array}$ \\
\hline 8 & $\begin{array}{l}\text { Counseling } \\
\text { Techniques }\end{array}$ & Mindfulness Technique: Figure 1, 2, 3, and 4 \\
\hline 9 & $\begin{array}{l}\text { Strengths } \\
\text { and } \\
\text { Weaknesses }\end{array}$ & $\begin{array}{l}\text { Strengths } \\
\text { - Helping the counselee to take an active attitude and take responsibility for himself. } \\
\text { - This approach can become the object of empirical testing where as a result the } \\
\text { theory and methods have been scientifically modified. }\end{array}$ \\
\hline
\end{tabular}




\begin{tabular}{l}
\hline No Aspect \\
\hline - The counseling system is open. Individuals who have not yet received advanced \\
training can still benefit from translating their therapeutic conditions into their \\
personal and professional lives. \\
- The basic concept is straightforward, easy to understand, and applicable. \\
- $\begin{array}{l}\text { Help free the individual from the shackles that hinder the process of enlightenment } \\
\text { (insight). }\end{array}$ \\
Weaknesses \\
- This approach tends to be dangerous if it is carried out by a counselor who is \\
passive or inactive, with limited response to reflection. \\
- The counselee needs direction, structured guidance and a counselor. \\
- $\begin{array}{l}\text { Minseles infulness counseling is difficult for counselors who are less experienced with } \\
\text { mindfulness practice. }\end{array}$ \\
- It takes experience and practice on an ongoing basis, so that the counselee can be \\
fully aware of change (impermanent), suffering, and something without a \\
permanent essence (eternal).
\end{tabular}

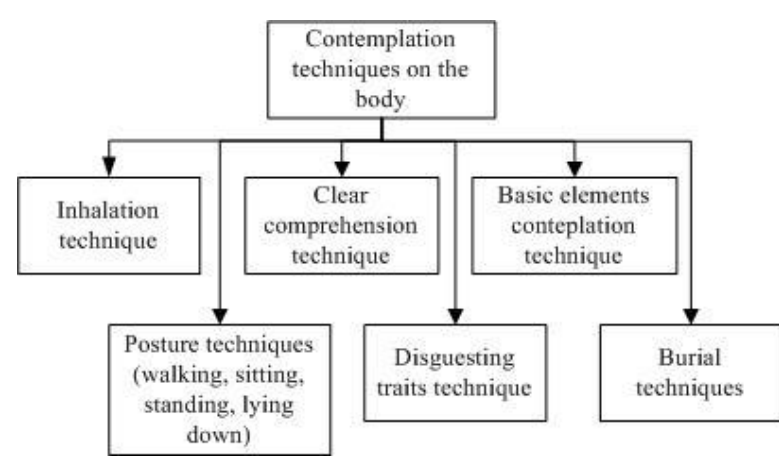

Figure 1. Contemplation techniques on the body

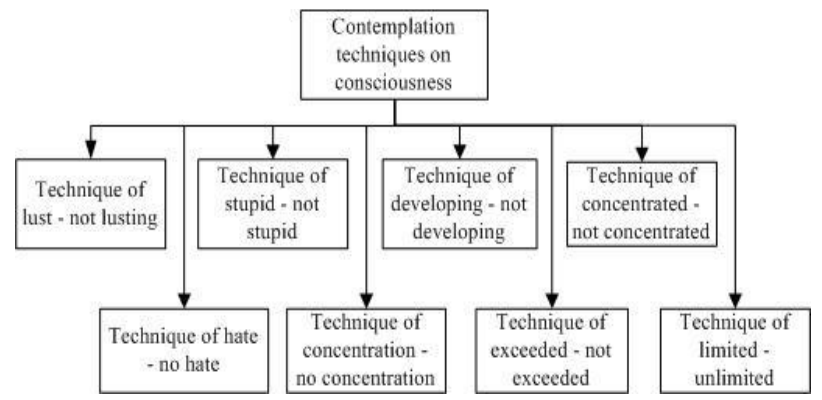

Figure 3. Contemplation techniques on consciousness

\section{Conclusions}

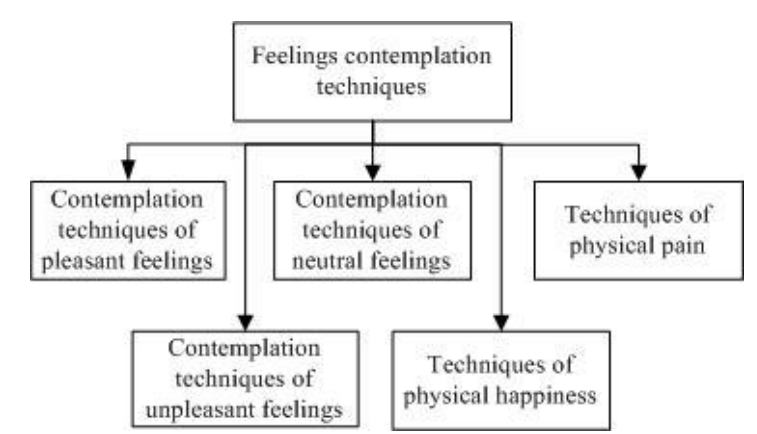

Figure 2. Technique of feelings contemplation

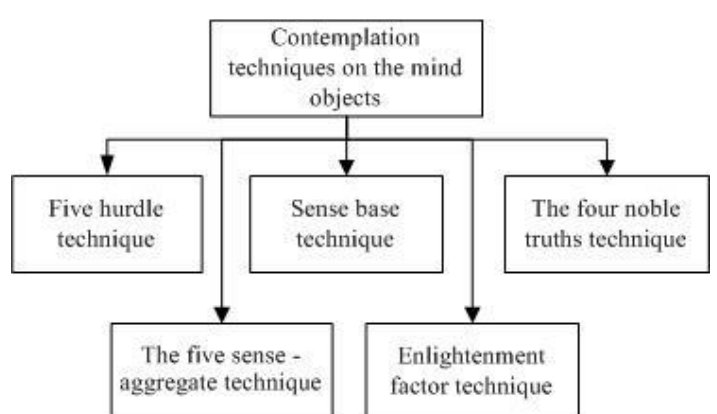

Figure 4. Technique of contemplation on mind objects

In the study of Buddhist mindfulness counseling, humans are seen to have the fundamental potential for happiness and suffering. Human nature consists of a combination of psychic (nāma) and physical (rüpa) in which both influence one another. It is aimed at purifying the mind, overcoming sorrow and anxiety, stopping physical and mental suffering, attaining insight and liberation of Nibbāna. The counselor in this case is a guide in the sense of being a good friend (kalyana mitta). The counselee's experience in counseling should have the ability to endure his whole life and have the potential to solve the problem or suffering he is facing. The quality of the positive therapeutic relationship between the counselee and the counselor should be built with empathy, warmth, understanding and acceptance and paying attention to blaming, ignoring or rejecting behavior.Through this research, it will help improve the understanding of students, lecturers, and counselors in the field of guidance and counseling or other sciences, namely by introducing mindfulness counseling to Buddhism. 


\section{References}

Adams, J. R. (2012). Spiritual issues in counseling: What do students perceive they are being taught? Counseling and Values, 57(1), 66-80. https://doi.org/10.1002/j.2161-007X.2012.00009.x

Amaro, A. (2015). A Holistic Mindfulness. Mindfulness, 6(1), 63-73. https://doi.org/10.1007/s12671-014$0382-3$

Analayo, B. (2006). Satipatthana Direct Path to Realization. Buddhist Wisdom Centre.

Bodhi, B. (2003). The Connected Discourses of the Buddha: A Translation of the Samyutta Nikaya. Wisdom Publications, Inc.

Bodhi, B. (2011). What does mindfulness really mean? A canonical perspective. Contemporary Buddhism, 12(1), 19-39. https://doi.org/10.1080/14639947.2011.564813

Bodhi, B. (2012). The Numerical Discourses of the Buddha: A Complete Translation of the Anguttara Nikaya (The Teachings of the Buddha). Wisdom Publication.

Brazier, C. (2013). Roots of mindfulness. European Journal of Psychotherapy and Counselling, 15(2), 127-138. https://doi.org/10.1080/13642537.2013.795336

Brown, A. P., Marquis, A., \& Guiffrida, D. A. (2013). Mindfulness-Based Interventions in Counseling. 91(1), 96104. https://doi.org/DOI:10.1002/j.1556-6676.2013.00077.x

Brown, K. W., \& Ryan, R. M. (2003). The benefits of being present: mindfulness and its role in psychological well-being. Journal of Personality and Social Psychology, 84(4), 822-848. https://doi.org/DOI: 10.1037/0022-3514.84.4.822

Cashwell Craig S, \& Young, J. S. (2013). Integrating Spirituality anf Religion Into Counseling: A guide to competent practice (2nd ed.). (Vol. 53, Issue 9). American Counseling Association.

Cheng, F. K. (2019). The Compatibility of Person-Centred Therapy and Buddhist Teachings. International Journal of Integrative Psychotherapy, 9(0), 1-55.

Cheryl L. Fulton, \& Cashwell, C. S. (2015). Mindfulness-based awareness and compassion: Predictors of counselor empathy and anxiety. Counselor Education and Supervision, 54, 122-133. https://doi.org/http://dx.doi.org/10.1002/ceas.12009. This

Choudhuri, D. D., \& Kraus, K. L. (2014). Buddhist perspectives for addressing values conflicts in counseling: Possibilities from practice. Journal of Counseling and Development, 92(2), 194-201. https://doi.org/10.1002/j.1556-6676.2014.00148.x

Daya, R. (2000). Buddhist psychology, a theory of change processes: Implications for counsellors. International Journal for the Advancement of Counselling, 22(4), 257-271. https://doi.org/10.1023/a:1005648127301

Didonna, F. (2009). Clinical handbook of mindfulness. In F. Didonna (Ed.), Clinical Handbook of Mindfulness. Springer Science Business Media. https://doi.org/10.1007/978-0-387-09593-6

Eells, G. T. (2012). Suffering and Meaning in Counseling Service Work: Theoretical Foundations and Therapeutic Responses. Journal of College Student Psychotherapy, 26(1), 39-49. https://doi.org/10.1080/87568225.2012.633043

Erford, B. T. (2015). 40 Techniques Every Sounselor Should Know (Issue May). Pearson Education, Inc.

Giraldi, T. (2019). Psychotherapy, Mindfulness and Buddhist Meditation. Palgrave Macmillan.

Gunaratana, V. H. (2011). Mindfulness In Plain English. Wisdom Publication.

Hoang, N. Q. (2019). The Doctrine of Not-self (anatta) in Early Buddhism. International Review of Social Research, 9(1), 18-27. https://doi.org/10.2478/irsr-2019-0003

Hofmann, S. G., Sawyer, A. T., Witt, A. A., \& Oh, D. (2010). The Effect of Mindfulness-Based Therapy on Anxiety and Depression: A Meta-Analytic Review. Journal of Consulting and Clinical Psychology, 78(2), 169-183. https://doi.org/10.1037/a0018555

Hoyt, M. (2016). Teaching with Mindfulness: The Pedagogy of Being-with/for and Without Being-with/for. Journal of Curriculum Theorizing, 31(1), 126-143.

Indunil Philip Shantha, W. G. (2019). Psychology of Buddhism and healing method of Japanese selfreflection. Trames, 23(3), 335-351. https://doi.org/10.3176/tr.2019.3.05

Ivers, N. N., Johnson, D. A., Clarke, P. B., Newsome, D. W., \& Berry, R. A. (2016). The Relationship between Mindfulness and Multicultural Counseling Competence. Journal of Counseling and Development, 94(1), 72-82. https://doi.org/10.1002/jcad.12063

Karunamuni, N., \& Weerasekera, R. (2019). Theoretical foundations to guide mindfulness meditation: A path to wisdom. Current Psychology, 38(3), 627-646.

Kabat-Zinn, J., Massion, A. O., Kristeller, J., Peterson, L. G., Fletcher, K. E., Pbert, L., Lenderking, W. R., \& Santorelli, S. F. (1992). Effectiveness of a meditation-based stress reduction program in the treatment of anxiety disorders. American Journal of Psychiatry, 149(7), 936-943. https://doi.org/10.1176/ajp.149.7.936

Kabat-Zinn, Jon. (1994). Wherever You Go There You Are. Hyperion. 
Kabat-Zinn, Jon. (2007). Wherever You Go, There You Are. Karaniya.

Kabat-Zinn, Jon. (2011). Some reflections on the origins of MBSR, skillful means, and the trouble with maps. Contemporary Buddhism, 12(1), 281-306. https://doi.org/10.1080/14639947.2011.564844

Lee, K. C. (George), \& Chez Kuang, O. (2018). the Satipatțhāna Sutta: an Application of Buddhist Mindfulness for Counsellors. Contemporary Buddhism, 19(2), 327-341. https://doi.org/10.1080/14639947.2018.1576292

Lee, K. C. (George), \& Oh, A. (2019). Introduction to compassionate view intervention: A Buddhist counseling technique based on Mahāyāna Buddhist teachings. Journal of Spirituality in Mental Health, 21(2), 132-151. https://doi.org/10.1080/19349637.2018.1464422

Lee, K. C. (George), Oh, A., Zhao, Q., \& Fang-Yi Wu, Shiyun Chen, Thomas Diaz, and C. K. O. (2017). Buddhist counseling: Implications for mental health professionals. Spirituality in Clinical Practice, 4(2), $1-$ 16. https://doi.org/10.1037/scp0000124

Leppma, M., \& Young, M. E. (2016). Loving-Kindness Meditation and Empathy: A Wellness Group Intervention for Counseling Students. Journal of Counseling and Development, 94(3), 297-305. https://doi.org/10.1002/jcad.12086

Luberto, C. M., Shinday, N., Philpotts, L., Park, E., Fricchione, G. L., \& Yeh, G. (2018). A systematic review of the effects of meditation on empathy, compassion, and pro-social behavior. Mindfulness, 9, 708-724. https://doi.org/doi.org/10.1007/s12671-017-0841-8

Lutz, A., Jha, A. P., Dunne, J. D., \& Saron, C. D. (2015). Investigating the phenomenological matrix of mindfulness-related practices from a neurocognitive perspective. American Psychologist, 70(7), 632-658. https://doi.org/10.1037/a0039585

Mahasi, S. (2006). Vipassana Meditation (Meditasi Vipasana). Karaniya.

Marma, A. (2017). Counseling and Its Importance: A Buddhist Perspective. Journal of the International Association of Buddhist Universities, 7(1), 29-41.

Nakayama, K. (2021). The Criticism of Theism in the Sravakabhumi of the Yogacarabhumi. Religions of South Asia, 15(1), 32-47-32-47.

O'Brien, V., \& Likis-Werle, E. (2020). Client Experiences of Mindfulness Meditation in Counseling: A Qualitative Study. Journal of Humanistic Counseling, 59(1), 20-37. https://doi.org/10.1002/johc.12127

O'Hagan, E. (2021). Grief, Love, and Buddhist Resilience. Journal of Value Inquiry, 55(1), 41-55. https://doi.org/10.1007/s10790-020-09737-2

Piet, J., \& Hougaard, E. (2011). The effect of mindfulness-based cognitive therapy for prevention of relapse in recurrent major depressive disorder: A systematic review and meta-analysis. Clinical Psychology Review, 31(6), 1032-1040. https://doi.org/10.1016/j.cpr.2011.05.002

Quek, J. (2007). The Buddha's Technique And Practice of Counselling as Depicted in the Pali Canon. KepMedia International Pte Ltd.

Rungreangkulkij, S., \& Wongtakee, W. (2008). The Psychological Impact of Buddhist Counseling for Patients Suffering From Symptoms of Anxiety. Archives of Psychiatric Nursing, 22(3), 127-134. https://doi.org/10.1016/j.apnu.2007.07.004

Safran, J. D. (2013). Psychoanalysis and Buddhism as cultural institutions. Crossroads in Psychoanalysis,

Buddhism, and Mindfulness: The Word and the Breath, 187.

Shapiro, S., Hanson, R., Carlson, K., Mustad, J., Robbins, M., Jha, A., Epel, E., Graham, J., Keltner, D., Nichols, W. J., \& Siegel, D. J. (2018). Masters of Mindfulness Transforming Your Mind and Body Course Guidebook. The Great Courses.

Shapiro, S. L., Carlson, L. E., Astin, J. A., \& Freedman, B. (2006). Mechanisms of mindfulness. In Journal of Clinical Psychology (Vol. 62, Issue 3, pp. 373-386). https://doi.org/DOI: 10.1002/jclp.20237

Shuler, M. K., \& Durodoye, B. A. (2007). A Review of Integrating Spirituality and Religion Into Counseling: A Guide to Competent Practice. Counseling and Values, 52(1), 89-91. https://doi.org/10.1093/sw/20.3.254-a

Stloukal, M. E., \& Wickman, S. A. (2011). School Counseling Programs as Spiritual and Religious Safe Zones. Counseling and Values, 55(2), 157-170. https://doi.org/http://dx.doi.org/10.1002/j.2161007X.2011.tb00029.x

Sun, J. (2014). Mindfulness in Context : A Historical Discourse Analysis. Contemporary Buddhism, 15(2), 394415. https://doi.org/10.1080/14639947.2014.978088

Surmitis, K. A., Fox, J., \& Gutierrez, D. (2018). Meditation and Appropriation: Best Practices for Counselors Who Utilize Meditation. Counseling and Values, 63(1), 4-16. https://doi.org/10.1002/cvj.12069

Susan M. Orsillo, L. R. (2005). Acceptance and Mindfulness-Based Aproaches to Anxiety: Conceptualization and Treatment. Spring.

Sutoyo, A. (2009). Bimbingan dan Konseling Islami (Islamic Guidance and Counseling). CV. Widya Karya Semarang. 
Ungsutharo, P. S., Siriwan, I., \& Ruangsanka, R. (2021). A Model of Human Resource Management based on Kalyanamitta Principles of Educational Institute Affiliated to Secondary Educational Service Area Office. $\quad$ Psychology and Education Journal, 58(2), 9428-9437

Tuicomepee, A., Romano, J. L., \& Pokaeo, S. (2012). Counseling in Thailand: Development from a Buddhist perspective. Journal of Counseling and Development, 90(3), 357-361. https://doi.org/10.1002/j.15566676.2012.00044.x

Wada, K., \& Park, J. (2009). Integrating Buddhist Psychology Into Grief Counseling. Death Studies, 33(7), 657-683. https://doi.org/DOI: 10.1080/07481180903012006

Warren, J. (2012). Applying Buddhist practices to recovery: What I learned from skiing with a little Buddha wisdom. Journal of Addictions and Offender Counseling, 33(1), 34-47. https://doi.org/10.1002/j.21611874.2012.00003. $\mathrm{x}$

Watts, R. E. (2001). Addressing Spiritual Issues in Secular Counseling and Psychotherapy: Response to Helminiak's (2001) Views. Counseling and Values, 45(April), 207-217.

Zed, M. (2018). Metode Penelitian Kepustakaan (Literature Research Methods). Yayasan Obor Indonesia.

Zinnbauer, B. J., \& Pargament, K. I. (2000). Working with the sacred: Four approaches to religious and spiritual issues in counseling. In Journal of Counseling and Development (Vol. 78, Issue 2). https://doi.org/10.1002/j.1556-6676.2000.tb02574.x

Zhou, J., Zheng, Y., Zeng, X., Jiang, M., \& Oei, T. P. (2021). A Randomized Controlled Trial Examining a Second-Generation Mindfulness-Based Intervention that is Compatible with Confucian Values: Mindfulness-Based Positive Psychology. Mindfulness, 12(6), 1412-1423. 